\title{
Landlocked Fall Chinook Salmon Egg Storage for Delayed Fertilization
}

\author{
Hunter Eide, Michael E. Barnes \\ South Dakota Department of Game, Fish and Parks, McNenny State Fish Hatchery, Spearfish, South Dakota, USA \\ Email: mike.barnes@state.sd.us
}

How to cite this paper: Eide, $\mathrm{H}$. and Barnes, M.E. (2020) Landlocked Fall Chinook Salmon Egg Storage for Delayed Fertilization. Advances in Bioscience and Biotechnology, 11, 160-165. https://doi.org/10.4236/abb.2020.115013

Received: April 5, 2020

Accepted: May 11, 2020

Published: May 14, 2020

Copyright $\odot 2020$ by author(s) and Scientific Research Publishing Inc. This work is licensed under the Creative Commons Attribution International License (CC BY 4.0).

http://creativecommons.org/licenses/by/4.0/

\section{(c) (i) Open Access}

\begin{abstract}
Delayed fertilization of salmonid eggs can be a useful option to enhance the efficiency of artificial spawning operations. This experiment examined the fertility of landlocked fall Chinook salmon (Oncorhynchus tshawytscha) eggs stored for various times after removal from female broodstock. Fertilization occurred either immediately after spawning or the eggs were stored with oxygen at $11^{\circ} \mathrm{C}$ and fertilized at $4,6,8,12$, or 20 hours post-spawn. Survival to the eyed stage of egg development was significantly greater in the eggs fertilized immediately or after four, six, or eight hours of storage compared to those eggs stored for 12 or 20 hours prior to fertilization $(P=0.024)$. Survival to hatch was also significantly different $(P=0.018)$ and followed the same pattern. This study is the first to document the successful fertilization of landlocked fall Chinook salmon eggs after eight hours of storage.
\end{abstract}

\section{Keywords}

Delayed Fertilization, Chinook Salmon, Egg Storage, Oncorhynchus tshawytscha

\section{Introduction}

Eggs removed from female trout and salmon are typically fertilized immediately with milt stripped from males during artificial spawning [1]. However, storing eggs for fertilization at a later time can be a viable option to improve spawning and egg incubation efficiencies [1] [2] [3] [4].

Temperature, duration, and the presence of oxygen have all been shown to affect the success of salmonid egg storage. In addition, the storage parameters may be somewhat species specific. Foerster [5] stored sockeye salmon (Oncorhynchus nerka) eggs for 25 hours at $5^{\circ} \mathrm{C}$ with no loss of fertility. However, storage at higher temperatures of $8^{\circ} \mathrm{C}$ or $10^{\circ} \mathrm{C}$ was detrimental. Also with sockeye salmon eggs, Withler and Morley [6] reported successful egg storage for 70 hours at 
$2.9^{\circ} \mathrm{C}$, with decreased fertility after 22 hours at storage temperatures of $9.9^{\circ} \mathrm{C}$. Withler and Morley [6] also observed that pink salmon (O. gorbuscha) egg fertility was maintained for 46 hours at $3.2^{\circ} \mathrm{C}$, but declined after only eight hours of storage at $8.5^{\circ} \mathrm{C}$. Similarly, Poon and Johnson [7] successfully stored pink salmon eggs for six hours at $6^{\circ} \mathrm{C}$. Chum salmon (O. keta) eggs can be stored for 124 hours at $3^{\circ} \mathrm{C}$ and maintain fertility, but such fertility exhibits a negative relationship between storage temperature and storage duration [8]. Unfertilized rainbow trout (O. mykiss) eggs stored at $2^{\circ} \mathrm{C}$ maintain fertility for 20 hours [9], but substantial declines in Chinook salmon (O. tshawytscha) egg fertility were reported after 48 hours of storage at $1^{\circ} \mathrm{C}$ [10]. Completely freshwater landlocked Chinook eggs stored at $10^{\circ} \mathrm{C}$ were only viable at storage durations of only two hours in air [11] [12]. However, the replacement of air with oxygen extended successful landlocked Chinook salmon egg storage times to four hours at $11^{\circ} \mathrm{C}$; fertility was reduced when stored four hours at $1^{\circ} \mathrm{C}$ even with the presence of oxygen [13].

Lake Oahe, South Dakota, USA, contains a relatively unique population of landlocked fall Chinook salmon maintained entirely by artificial propagation [14] [15] [16]. With spawning operations occurring as far as $365 \mathrm{~km}$ from egg incubation facilities, storage of unfertilized eggs could be advantageous. The longest these landlocked Chinook salmon eggs have been successfully stored has been only four hours [13]. Thus, the objective of this was to potentially increase egg storage times.

\section{Methods}

Landlocked fall Chinook salmon from Lake Oahe were spawned at Whitlock's Spawning Station, near Gettysburg, South Dakota, USA on October 21, 2019. Milt was collected from males, pooled in a container, and approximately $50 \mathrm{~mL}$ placed into each of six $0.95 \mathrm{~L}$ plastic bags. Each bag corresponded to a delayed-fertilization treatment. Oxygen was added to each bag of milt prior to sealing, after which the bag was placed on ice until used for fertilization. Eggs from three female salmon were pneumatically expressed using compressed oxygen and combined into a common pool. Thirty-six aliquots containing 15 eggs each were removed from the pool, with each aliquot placed into a discrete $0.95 \mathrm{~L}$ plastic bag. Each of the 36 bags was assigned to one of six treatments $(N=6)$, with the eggs either being fertilized immediately or with fertilization delayed until four, six, eight, 12, or 20 hours later.

Fertilization occurred by adding one $\mathrm{mL}$ of milt from the assigned bag. The sperm were then activated using well water (total hardness as $\mathrm{CaCO}_{3}, 360 \mathrm{mg} / \mathrm{L}$; alkalinity as $\mathrm{CaCO}_{3}, 210 \mathrm{mg} / \mathrm{L} ; \mathrm{pH}, 7.6$; total dissolved solids, $390 \mathrm{mg} / \mathrm{L}$ ) to the egg/milt mixture. After approximately one minute, the eggs were rinsed with lake water and each bag of eggs was placed into a discrete $9.5-\mathrm{cm}$ plastic Petri dish filled with $30 \mathrm{~mL}$ of well water for incubation using the technique described by Neumiller et al. [17]. Water in the Petri dishes was changed every seven days 
before the eyed egg stage of development and every three days after. Dead eggs were removed and counted when the water was changed. Fry were also removed and counted after hatch. The dishes were incubated in an Insignia model NS-WC16BK6 refrigeration unit (Best Buy, Richfield, Minnesota, USA) at $10^{\circ} \mathrm{C}$ through complete hatch.

Data were analyzed by one-way Analysis of Variance (ANOVA) using the SPSS (24.0) statistical analysis program (IBM, Chicago, Illinois, USA). Fisher's Protected Least Significant Difference was used as the mean comparison procedure. Significance was pre-determined at $\mathrm{P}<0.05$.

\section{Results}

Eggs fertilized immediately or after four, six, or eight hours of storage had significantly greater survival to the eyed stage $\left(\mathrm{F}_{(5,30)}=3.045 ; \mathrm{P}=0.024\right)$ than eggs stored for 12 or 20 hours prior to fertilization (Table 1). Survival to hatch was also significantly different $\left(\mathrm{F}_{(5,30)}=3.0257 ; \mathrm{P}=0.018\right)$ and followed the same pattern. Mean survival to hatch ranged from $46.7 \%$ for eggs fertilized immediately to $18.9 \%$ for the eggs fertilized after twelve hours of storage.

\section{Discussion}

The results of this study describe for the first time the storage of landlocked Chinook salmon eggs for up to eight hours without the loss of fertility. This is four hours longer than previously reported by Eide and Barnes [13], who also noted the need for air replacement with compressed oxygen during landlocked Chinook salmon egg storage. Oxygen has also been associated with longer egg storage times in other salmonid species [5] [6] [8] [9]. Compared to other studies examining salmonid egg storage though, eight hours is a relatively short period of time, with 124 hours the longest successful storage time reported for salmonid eggs by Jensen and Alderdice [8].

Although a negative relationship between egg storage temperatures and storage times has been observed for numerous salmonids [6] [8], this appears not to

Table 1. Mean (SE) survival to the eyed-stage or hatch of landlocked fall Chinook salmon eggs either fertilized immediately or after storage of up to 20 hours.* $^{*}$

\begin{tabular}{ccc}
\hline Storage time $(\mathrm{h})$ & Eye $(\%)$ & Hatch $(\%)$ \\
\hline 0 & $51.1(4.1) \mathrm{z}$ & $46.7(4.5) \mathrm{z}$ \\
4 & $42.2(7.0) \mathrm{z}$ & $41.1(8.0) \mathrm{z}$ \\
6 & $40.0(7.1) \mathrm{z}$ & $38.9(6.5) \mathrm{z}$ \\
8 & $38.9(5.8) \mathrm{z}$ & $37.8(5.6) \mathrm{z}$ \\
12 & $23.3(6.4) \mathrm{y}$ & $18.9(5.0) \mathrm{y}$ \\
20 & $23.3(7.0) \mathrm{y}$ & $22.2(6.6) \mathrm{y}$ \\
$\mathrm{P}$ & 0.024 & 0.018 \\
\hline
\end{tabular}

${ }^{*}$ Means in a column followed by different letters are significantly different $(\mathrm{N}=6)$. 
be the case with landlocked Chinook salmon. Eide and Barnes [13] reported a significant drop in stored landlocked Chinook salmon egg fertility at temperatures of $1^{\circ} \mathrm{C}$ compared to $11^{\circ} \mathrm{C}$ with storage times as short as four hours. Thus, it is unlikely that decreasing the temperature used in this present study would have led to increased storage times.

Short-term landlocked Chinook salmon sperm motility after storage on ice was reported by Reese et al. [18]. In addition, Bencic et al. [19] successfully stored Chinook salmon milt for 14 days, and salmonid milt in general has been stored for over 30 days [20]. These studies, in conjunction with using oxygen during milt storage [6] [21] [22] [23] in the present study, make it unlikely that milt storage had any impact on the results.

The egg survival observed in this study is typical for landlocked fall Chinook salmon from Lake Oahe [15] [16]. The reproductive characteristics of this non-native population of freshwater Chinook salmon are completely different than those of Chinook salmon in their native range [15] [16]. These unique features may explain why the successful egg storage times and temperatures observed in this study appear to be markedly different than those observed in other populations [1] [10].

\section{Conclusion}

In conclusion, this study documents the first successful storage of landlocked Chinook salmon eggs for eight hours. Future experiments should determine the effects of different temperatures during longer storage periods.

\section{Acknowledgements}

We thank Shon Eide, Gerri Eide, Jill Voorhees, Robert Hanten, and the staff at Whitlock's Salmon Spawning Station for their assistance with this study.

\section{Conflicts of Interest}

The authors declare no conflicts of interest regarding the publication of this paper.

\section{References}

[1] Leitritz, E. and Lewis, R.C. (1976) Trout and Salmon Culture (Hatchery Methods). California Department of Fish and Game, Sacramento, Fish Bulletin 164.

[2] Stoss, J. (1983) 6 Fish Gamete Preservation and Spermatozoan Physiology. Fish Physiology Part B, 9, 305-350. https://doi.org/10.1016/S1546-5098(08)60306-4

[3] Bromage, N.R. and Roberts, R.J. (1995) Broodstock Management and Egg and Larval Quality. Blackwell Science, Oxford.

[4] Quinn, T.P., Peterson, J.A., Gallucci, V.F., Hershberger, W.K. and Brannon, E.L. (2002) Artificial Selection and Environmental Change: Countervailing Factors Affecting the Timing of Spawning by Coho and Chinook Salmon. Transactions of the American Fisheries Society, 131, 591-598. https://doi.org/10.1577/1548-8659(2002)131<0591:ASAECC>2.0.CO;2 
[5] Foerster, R.E. (1965) Effect of Retention of Spermatozoa and Ova of Sockeye Salmon, Oncorhynchus nerka, in Water and without Addition of Water, on Fertility. Journal of the Fisheries Research Board of Canada, 22, 1503-1521. https://doi.org/10.1139/f65-129

[6] Withler, F.C. and Morley, R.B. (1968) Effects of Chilled Storage on Viability of Stored Ova and Sperm of Sockeye and Pink Salmon. Journal of the Fisheries Board of Canada, 25, 2695-2699. https://doi.org/10.1139/f68-240

[7] Poon, D.C. and Johnson, A.K. (1970) The Effect of Delayed Fertilization on Transported Salmon Eggs. Progressive Fish-Culturist, 32, 81-84. https://doi.org/10.1577/1548-8640(1970)32[81:TEODFO]2.0.CO;2

[8] Jensen, J. and Alderdice, D. (1984) Effect of Temperature on Short-Term Storage of Eggs and Sperm of Chum Salmon (Oncorhynchus keta). Aquaculture, 37, 251-265. https://doi.org/10.1016/0044-8486(84)90158-3

[9] Ginatullina, E., Komrakova, M. and Holtz, W. (2018) Chilled Storage of Unfertilized and Fertilized Rainbow Trout (Oncorhynchus mykiss) Eggs in Sealed Polyethylene Bags at Different Temperatures. Aquaculture, 484, 214-218.

https://doi.org/10.1016/j.aquaculture.2017.11.028

[10] Piper, R.G., McElwain, I.B., Orme, L.E., McCraren, J.P., Fowler, L.G. and Leonard, J.R. (1982) Fish Hatchery Management. U.S. Fish and Wildlife Service, Washington DC.

[11] Barnes, M.E., Sayler, W.A. and Cordes, R.J. (1999) Transportation Influences on Inland Fall Chinook Salmon Egg Survival. North American Journal of Aquaculture, 61, 27-33. https://doi.org/10.1577/1548-8454(1999)061<0027:TIOIFC >2.0.CO;2

[12] Eide, H. and Barnes, M. (2018) Survival of Lake Oahe Chinook Salmon Eggs after Delayed Fertilization. International Journal of Innovative Studies in Aquatic Biology and Fisheries, 4, 14-18.

[13] Eide, H. and Barnes, M. (2019) Delayed Fertilization of Lake Oahe Chinook Salmon Eggs Stored with Oxygen at Two Temperatures. International Journal of Fisheries Science and Research, 3, 1011.

[14] Lott, J., Marrone, G. and Stout, D. (1997) Influence of Size-and-Date at Stocking, Imprinting Attempts and Growth on Initial Survival, Homing Ability, Maturation Patterns and Angler Harvest of Chinook Salmon in Lake Oahe, South Dakota. South Dakota Department of Game, Fish and Parks, Pierre, Progress Report 97-20.

[15] Barnes, M.E., Hanten, R.P., Cordes, R.J., Sayler, W.A. and Carreiro, J. (2000) Reproductive Performance of Inland Fall Chinook Salmon. North American Journal of Aquaculture, 62, 203-211. https://doi.org/10.1577/1548-8454(2000)062<0203:RPOIFC>2.3.CO;2

[16] Young, K.L., Barnes, M.E. and Kientz, J.L. (2016) Reproductive Characteristics of Lake Oahe Chinook Salmon from Lake Oahe, South Dakota. Prairie Naturalist, 48, 79-86.

[17] Neumiller, H.K., Blain, G.A. and Barnes, M.E. (2017) Incubation of Lake Oahe Chinook Salmon Eggs in Petri Dishes. North American Journal of Aquaculture, 79, 183-186. https://doi.org/10.1080/15222055.2017.1281854

[18] Reese, S.E., Long, A.J., Meyer, H.A. and Barnes, M.E. (2017) Lake Oahe Chinook Salmon Sperm Motility after Short Term Milt Storage. International Journal of Innovative Studies in Aquatic Biology and Fisheries, 3, 9-13. https://doi.org/10.20431/2454-7670.0301002

[19] Bencic, D.C., Ingermann, R.L. and Cloud, J.G. (2001) Does $\mathrm{CO}_{2}$ Enhance Short-Term 
Storage Success of Chinook Salmon (Oncorhynchus tshawytscha) Milt? Theriogenology, 56, 157-166. https://doi.org/10.1016/S0093-691X(01)00551-9

[20] Stoss, J. and Holtz, W. (1983) Successful Storage of Chilled Rainbow Trout (Salmo gairdneri) Spermatozoa for up to 34 Days. Aquaculture, 31, 269-274. https://doi.org/10.1016/0044-8486(83)90318-6

[21] Stoss, J., Büyükhatipoglu, S. and Holtz, W. (1978) Short-Term and Cryopreservation of Rainbow Trout (Salmo gairdneri) Sperm. Annales Biology Animal Biochemistry Biophysics, 18, 1077-1082. https://doi.org/10.1051/rnd:19780549

[22] Scott, A.P. and Baynes, S.M. (1980) A Review of the Biology, Handling and Storage of Salmonid Spermatozoa. Journal of Fish Biology, 17, 707-739. https://doi.org/10.1111/j.1095-8649.1980.tb02804.x

[23] Billard, R. (1981) Short-Term Preservation of Sperm under Oxygen Atmosphere in Rainbow Trout (Salmo gairdneri). Aquaculture, 23, 287-293.

https://doi.org/10.1016/0044-8486(81)90022-3 